\title{
AL-IQTISHADIYAH
}

Jurnal Ekonomi Syariah dan Hukum Ekonomi Syariah

E-ISSN: 2621-0274; P-ISSN: 2442-2282

Volume 6, Nomor 2, Desember 2020

\section{PENGARUH KEPEMIMPINAN, LINGKUNGAN KERJA, DAN PENDIDIKAN TERHADAP KINERJA KARYAWAN (STUDI PADA PABRIK GULA REJO AGUNG BARU MADIUN)}

\author{
Maulida Nurhidayati ${ }^{1}$ \& Sovia Zahrianti Erika ${ }^{2}$ \\ 1 Fakultas Ekonomi dan Bisnis Islam, Institut Agama Islam Negeri Ponorogo, Indonesia. Email: \\ nurhidayati@iainponorogo.ac.id \\ 2 Mahasiswa Pascasarjana, Institut Agama Islam Negeri Ponorogo, Indonesia Email: \\ kaksoviazahrianti@gmail.com
}

\section{ARTICLE INFO}

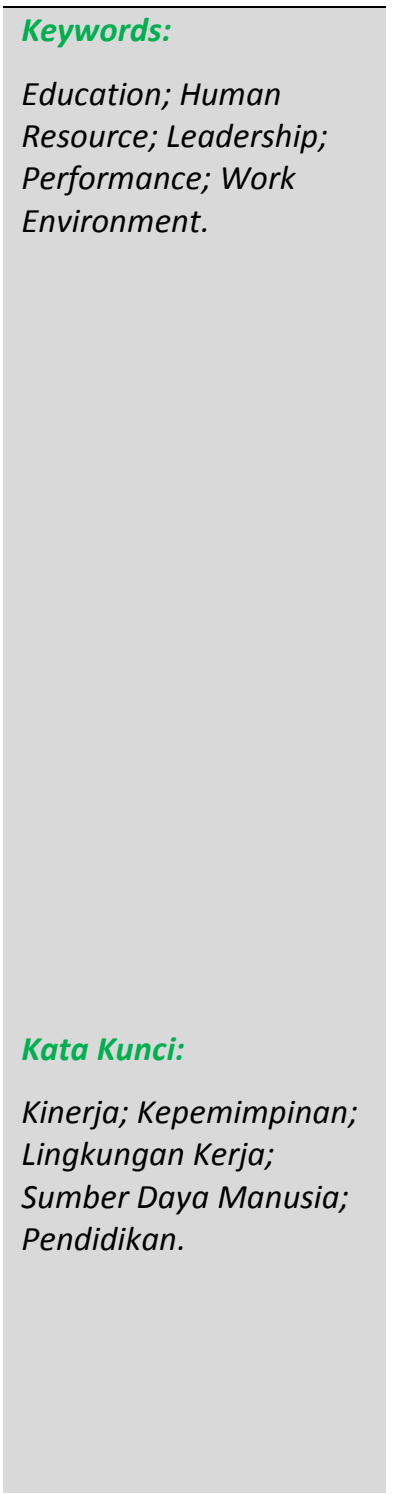

\section{ABSTRACT}

Increasingly tight competition between companies resulted in a company having to start improving conditions within the company itself. This is done to prepare to compete with other companies. Stable and high employee performance can improve performance and profit for the company. Rejo Agung Baru Madiun Sugar Factory (PG) has employee productivity shown by the increase in the company's profit. The profit earned by the company tends to be unstable indicated by the increase and decrease in profit earned each year. In the past two years, however, the company's profits have started to show an increasing trend. This condition is interesting to be associated with the theory of Cashmere as well as the theory of Suparno Eko Widodo. This research was conducted with the aim of knowing the influence of leadership, work environment, and education on the performance of PG Rejo Agung Baru Madiun employees simultaneously and partially. The data was obtained by providing questionnaires to 72 permanent employees. Multiple linear regression with dummy variables was chosen as an analytical method to achieve research objectives. The results of the study stated that there is a partial or simultaneous influence between leadership, work environment, and education affecting employee performance. The amount of contribution given by these three variables to employee performance was $67.5 \%$ while $32.5 \%$ was explained by variables not researched in the model..

\section{ABSTRAK}

Persaingan yang semakin ketat antar perusahaan mengakibatkan suatu perusahaan harus mulai memperbaiki kondisi didalam perusahaan itu sendiri. Hal ini dilakukan untuk mempersiapkan diri bersaing dengan perusahaan lain. Kinerja karyawan yang stabil dan tinggi mampu meningkatkan performansi dan keuntungan bagi perusahaan. Pabrik Gula (PG) Rejo Agung Baru Madiun memiliki produktivitas karyawan yang ditunjukkan dengan meningkatnya laba perusahaan. Laba yang diperoleh perusahaan cenderung tidak stabil yang ditunjukkan dengan kenaikan dan penurunan laba yang diperoleh setiap tahunnya. Akan tetapi dua tahun belakangan ini, laba perusahan mulai menunjukkan tren meningkat. Kondisi ini menarik 


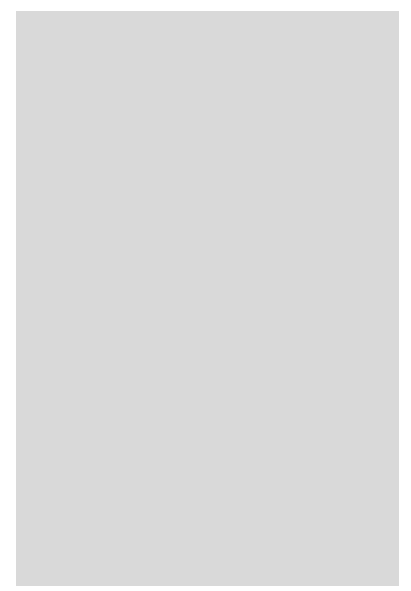

untuk dihubungkan teori Kasmir serta teori Suparno Eko Widodo. Penelitian ini dilakukan dengan tujuan mengetahui pengaruh kepemimpinan, lingkungan kerja, dan pendidikan terhadap kinerja karyawan PG Rejo Agung Baru Madiun secara simultan maupun parsial. Data diperoleh dengan memberikan angket/kuesioner ke 72 karyawan tetap. Regresi linier berganda dengan variabel dummy dipilih sebagai metode analisis untuk mencapai tujuan penelitian. Hasil dari penelitian menyatakan terdapat pengaruh secara parsial maupun simultan antara kepemimpinan, lingkungan kerja, dan pendidikan berpengaruh terhadap kinerja karyawan. Besarnya kontribusi yang diberikan ketiga variabel tersebut terhadap kinerja karyawan adalah $67,5 \%$ sedangkan $32,5 \%$ dijelaskan oleh variabel yang tidak diteliti dalam model.

\section{Pendahuluan}

Pabrik Gula (PG) Rejo Agung Baru Madiun adalah unit cabang dari PT Pabrik Gula Rajawali 1 yang berpusat di Jakarta yang merupakan BUMN (Badan Usaha Milik Negara). PG Rejo Agung Baru Madiun ini berlokasi di Kecamatan Mangunharjo Kota Madiun. PG Rejo Agung Baru Madiun melaksanakan produksi gula satu tahun sekali sekitar bulan Mei hingga September. Laba kotor yang diperoleh oleh PG Rejo Agung Baru Madiun ini cenderung tidak stabil seperti diperlihatkan pada Tabel 1.

Tabel 1. Laba Kotor PG Rejo Agung Baru Madiun Periode 2014-2019

\begin{tabular}{cc}
\hline Tahun & Laba Kotor (dalam Milyar Rupiah) \\
\hline 2014 & 17 \\
\hline 2015 & 92 \\
\hline 2016 & 58 \\
\hline 2017 & 23 \\
\hline 2018 & 25 \\
\hline 2019 & 50
\end{tabular}

Sumber: Bagian Keuangan PG Rejo Agung Baru Madiun (2019)

Berdasarkan Tabel 1 diketahui bahwa pada Tahun 2014 laba kotor yang diterima PG Rejo Agung Madiun adalah 17 Milyar Rupiah. Pada Tahun 2015, laba kotor meningkat hingga 92 Milyar Rupiah. Setelah terjadi peningkatan pada tahun 2015, laba kotor yang diterima PG Rejo Agung Baru Madiun mulai menurun pada tahun 2016 (58 Milyar Rupiah) dan menurun lagi pada tahun 2017 (23 Milyar Rupiah). Pada Tahun 2018, laba kotor yang diperoleh mulai menunjukkan peningkatan menjadi 25 Milyar Rupiah. Pada Tahun 2019 mengalami peningkatan dua kali lipat menjadi 50 Milyar Rupiah dibandingkan laba kotor pada tahun sebelumnya. Peningkatan atau penurunan laba kotor yang dikarenakan adanya peningkatan atau penurunan hasil giling serta dipengaruhi oleh kenaikan atau penurunan harga gula pasir. 
Berdasarkan hasil wawancara dengan Ibu Retno Sadkeksi (staf karyawan) pada tanggal 7 Januari 2020 diketahui bahwa gula kristal putih yang diproduksi sudah melewati proses quality control yang ketat sesuai dengan standar perusahaan dan sertifikasi ISO 9001-2015 sehingga proses produksi sesuai dengan standar perusahaan. Selain proses produksi yang telah terstandar, kualitas produk gula kristal putih juga telah memiliki standar sesuai dengan yang ditetapkan perusahaan. Peningkatan laba bruto yang terjadi di tahun 2019 dan kualitas gula kristal putih yang terjamin sesuai sertifikasi ISO 9001-2015 menjadi salah satu indikasi terjadinya peningkatan kinerja karyawan sesuai dengan pendapat yang dikemukakan oleh Suparyadi, bahwa indikator dari kinerja karyawan adalah kuantitas dan kualitas. ${ }^{1}$ Artinya kinerja karyawan meningkat ketika terjadi peningkatan pada kuantitas dan kualitas barang yang dihasilkan.

Kinerja karyawan menurut Supriyadi adalah suatu hasil kerja yang diraih seorang karyawan sesuai beban dan tugas yang diberikan kepadanya yang dapat diukur kualitas dan kuantitasnya. ${ }^{2}$ Menurut Benardin dan Russel, kinerja adalah hasil yang diperoleh dalam periode waktu tertentu sesuai fungsi dan kegiatan pada bidang pekerjaan tertentu. Hasil kerja ini diperoleh dari kemampuan, keahlian, dan keinginan dari karyawan. ${ }^{3}$ Artinya, kinerja karyawan merupakan hasil pekerjaan karyawan sesuai dengan kemampuan yang dimiliki berdasarkan tanggung jawab dan tugas yang diberikan perusahaan. Kinerja karyawan dikatakan baik ketika hasil pekerjaan yang dilakukan sesuai dengan kualitas dan kuantitas yang diinginkan perusahaan. Menurut Kasmir, kinerja karyawan dipengaruhi oleh kepemimpinan dan lingkungan kerja. ${ }^{4}$ Sedangkan menurut Simanjutak, kinerja karyawan dipengaruhi oleh pendidikan/pelatihan yang merupakan wujud dari kualitas dan kemampuan karyawan. ${ }^{5}$

Kepemimpinan adalah salah satu faktor yang memengaruhi kinerja karyawan yang didukung hasil penelitian Siti Maisaroh Hasibuan dan Saiful Bahri yang memperlihatkan bahwa kepemimpinan memberi pengaruh yang positif terhadap kinerja karyawan. ${ }^{6}$ Kepemimpinan diartikan sebagai proses yang dilakukan pemimpin/pimpinan dalam memberikan arahan dan memengaruhi karyawan agar

\footnotetext{
${ }^{1}$ Suparyadi, Manajemen Sumber Daya Manusia (Yogyakarta: Andi Offset, 2015), 313.

2 Anwar Prabu Mangkunegara, Manajemen Sumber Daya Manusia Perusahaan (Bandung: Remaja, 2013), 67.

${ }^{3}$ Donni Juni Priansa, Perencanaan dan Pengembangan Sumber Daya Manusia (Bandung: Alfabeta, 2016), 270.

${ }^{4}$ Kasmir, Manajemen Sumber Daya Manusia (Teori dan Praktik) (Jakarta: Rajawali Pers, 2016), 189.

${ }^{5}$ Suparno Eko Widodo, Manajemen Pengembangan Sumber Daya Manusia (Yogyakarta: Pustaka Pelajar, 2015), 133.

${ }^{6}$ Siti Maisarah Hasibuan dan Syaiful Bahri, "Pengaruh Kepemimpinan, Lingkungan Kerja dan Motivasi Kerja Terhadap Kinerja," Maneggio: Jurnal IImiah Magister Manajemen 1, no. 1 (2018): 78, https://doi.org/10.30596/maneggio.v1i1.2243.
} 
mampu melaksanakan tugas yang telah diberikan. ${ }^{7}$ Kepemimpinan merupakan bagian terpenting dalam perusahaan karena kepemimpinan yang baik dan optimal bisa digunakan untuk mengelola SDM dan SDA perusahaan dan memanfaatkannya secara optimal. ${ }^{8}$ Dalam sudut pandang lain, Chung dan Megginson menyatakan bahwa kepemimpinan adalah kemampuan/keahlian dalam memengaruhi perilaku orang lain sesuai dengan arah tertentu. ${ }^{9}$ Dalam perkembangan kinerja karyawan, unsur kepemimpinan dinilai sangat berpengaruh. Pemberian arahan dan motivasi perlu dilakukan oleh pemimpin perusahaan kepada karyawannya.

Faktor kedua setelah kepemimpinan adalah lingkungan kerja. Penelitian Apfia Ferawati ${ }^{10}$ dan Daniel Surjosuseno ${ }^{11}$ yang memperlihatkan bahwa lingkungan kerja mampu memberikan pengaruh yang positif pada kinerja karyawan. Suatu keadaan yang di sekeliling karyawan dan memengaruhi karyawan menyelesaikan tugas yang diberikan disebut lingkungan kerja. ${ }^{12}$ Lingkungan kerja mampu memberikan dampak positif maupun negatif kepada karyawan dalam menyelesaiakan pekerjaannya. Secara umum, lingkungan kerja tidak berpengaruh secara langsung terhadap proses produksi suatu perusahaan, akan tetapi mampu memengaruhi karyawan yang melakukan tugas dalam proses produksi. ${ }^{13}$ Artinya lingkungan kerja mendukung proses produksi ketika dikondisikan dengan baik dan nyaman.

Lingkungan kerja memiliki peran penting terhadap keberlangsungan suatu perusahaan. Kondisi PG Rejo Agung Baru Madiun yang pada dasarnya bangunan pabrik era kolonial membuat suasana menjadi seperti tempo dulu. Keadaan bangunan yang sudah tua juga sangat beresiko bagi karyawan yang bekerja di dalamnya terutama bangunan pabrik yang digunakan untuk produksi bersinggungan langsung dengan mesin-mesin yang beroperasi. Ruang pengolahan limbah ampas masih berdindingkan seng, yang mana juga sangat beresiko saat bekerja.

Faktor ketiga setelah kepemimpinan dan lingkungan kerja yang memberikan pengaruh terhadap kinerja adalah pendidikan. Penelitian Desak Ketut Ratna Dewi dkk ${ }^{14}$ dan

\footnotetext{
${ }^{7}$ Ernie Tisnawati Sule dan Kurniawan Saifullah, Pengantar Manajemen (Jakarta: Prenadamedia Group, 2015), 255.

${ }^{8}$ Sudarmayanti, Manajemen Sumber Daya Manusia (Bandung: CV. Mandar Maju, 2011), 249.

${ }^{9}$ Wilson Bangun, Manajemen Sumber Daya Manusia (Jakarta: Erlangga, 2012), 337.

${ }^{10}$ Apfia Ferawati, "Pengaruh Lingkungan Kerja Dan Disiplin Kerja Terhadap Kinerja Karyawan Pt. Cahaya Indo Persada," Jurnal Agora 5, no. 1 (2017): 131.

${ }^{11}$ Daniel Surjosuseno, "Pengaruh Lingkungan Kerja Dan Motivasi Kerja Terhadap Kinerja Karyawan Pada Bagian Produksi UD Pabrik Ada Plastic,” Agora 3, no. 2 (20 November 2015): 177.

12 Alex S Nitisemito, Manajemen Personalia: Manajemen Sumber Daya Manusia (Jakarta: Ghalia Indonesia, 1983), 183.

${ }^{13}$ Mariati Rahman, Ilmu Administrasi (Makasar: Sah Media, 2017), 45.

14 Desak Ketut Ratna Dewi, I Wayan Suwendra, dan Ni Nyoman Yulianthini, "Pengaruh Tingkat Pendidikan dan Motivasi Kerja terhadap Kinerja Karyawan," Jurnal Manajemen Indonesia 4, no. 1 (2016).
} 
Ketut Edy Wirawan dkk. ${ }^{15}$ memperlihatkan bahwa kinerja karyawan dipengaruhi oleh tingkat pendidikan. Pendidikan karyawan PG Rejo Agung Baru Madiun meliputi SMA, D3, S1 maupun S2. Pendidikan ini sangat menentukan penempatan kerja karyawan. Karyawan dengan pendidikan SMA biasanya ditempatkan dibagian lapangan atau termasuk dalam karyawan non staff. Sedangkan karyawan yang memiliki pendidikan minimal D3 akan ditempatkan sebagai karyawan staff.

Kinerja karyawan yang baik akan sangat memengaruhi performansi dari PG Rejo Agung Baru Madiun maupun karyawan itu sendiri. Jika karyawan bekerja dengan efektif dan efisien maka performansi perusahaan menjadi baik. Oleh karena itu, kinerja karyawan menjadi tolak ukur kemajuan suatu perusahaan. Pentingnya kinerja karyawan mengakibatkan banyak penelitian yang membahas tentang kinerja karyawan. Penelitian Wa Ode Zusnita muizu dkk ${ }^{16}$, Dwi Yuniarti dan Erlian Suprianto ${ }^{17}$, Made Suprapta dkk ${ }^{18}$ serta Sri Rustilah ${ }^{19}$ memperlihatkan bahwa kepemimpinan memberikan pengaruh yang positif terhadap kinerja karyawan. Penelitian oleh Tomy Sun Siagian dan Hazmanan Khair ${ }^{20}$, Fernando Reinhard Tjiabrata dkk ${ }^{21}$, Rizal Nabawi ${ }^{22}$, serta Elizar dan Hasrudy Tanjung ${ }^{23}$ memperlihatkan bahwa lingkungan kerja memberikan pengaruh yang positif terhadap kinerja karyawan. Sementara itu,

\footnotetext{
${ }^{15}$ Ketut Edy Wirawan, I Wayan Bagia, dan Gede Putu Agus Jana Susila, "Pengaruh Tingkat Pendidikan Dan Pengalaman Kerja Terhadap Kinerja," Bisma Jurnal Manajamen 5, no. 1 (2019): 60.

${ }^{16}$ Wa Ode Zusnita Muizu, Umi Kaltum, dan Ernie T Sule, “Pengaruh Kepemimpinan Terhadap Kinerja Karyawan," PERWIRA-Jurnal Pendidikan Kewirausahaan Indonesia 2, no. 1 (2019): 75.

${ }^{17}$ Dwi Yuniarti dan Erlian Suprianto, “Pengaruh Gaya Kepemimpinan Dan Tingkat Pendidikan Terhadap Kinerja Karyawan Pada Direktoreat Operasi/Produksi Pt. X," Jurnal Industri Elektro dan Penerbangan 4, no. 1 (2020): 11.

${ }^{18}$ Made Suprapta, Desak Ketut Sintaasih, dan I Gede Riana, "Pengaruh kepemimpinan terhadap kepuasan kerja dan kinerja karyawan (studi pada Wake Bali Art Market Kuta-Bali)," E-Jurnal Ekonomi dan Bisnis Universitas Udayana, 2015, 437.
}

${ }^{19}$ Sri Rustilah, “Pengaruh Gaya Kepemimpinan Dan Kompensasi Terhadap Kepuasan Kerja Dan Kinerja Pegawai Tenaga Kontrak," Journal of Management Review 2, no. 2 (2018): 219, https://doi.org/10.25157/jmr.v2i2.1798.

20 Tomy Sun Siagian dan Hazmanan Khair, “Pengaruh Gaya Kepemimpinan Dan Lingkungan Kerja Terhadap Kinerja Karyawan Dengan Kepuasan Kerja Sebagai Variabel Intervening," Maneggio: Jurnal Ilmiah Magister Manajemen 1, no. 1 (2018): 65, https://doi.org/10.30596/maneggio.v1i1.2241.

${ }^{21}$ Fernando Reinhard Tjibrata, Bode Lumanaw, dan Lucky Dotulang O.H, "Pengaruh Beban Kerja Dan Lingkungan Kerja Terhadap Kinerja Karyawan Pt.Sabar Ganda Manado," Jurnal EMBA 5 No.2, no. Juni (2017): 1578.

22 Rizal Nabawi, "Pengaruh Lingkungan Kerja, Kepuasan Kerja dan Beban Kerja Terhadap Kinerja Pegawai," Maneggio: Jurnal Ilmiah Magister Manajemen 2, no. 2 (2019): 170, https://doi.org/10.30596/maneggio.v2i2.3667.

${ }^{23}$ Elizar Elizar dan Hasrudy Tanjung, "Pengaruh Pelatihan, Kompetensi, Lingkungan Kerja terhadap Kinerja Pegawai," Maneggio: Jurnal Ilmiah Magister Manajemen 1, no. 1 (2018): 46, https://doi.org/10.30596/maneggio.v1i1.2239. 
penelitian Kadek Candra Dwi Cahyani $\mathrm{dkk}^{24}$, Miranda Diah Ratnasari dan Bambang Swasti Sunuharyo ${ }^{25}$, Iswaranti Patarai dkk ${ }^{26}$ serta Wenda Jennifer Rori dkk ${ }^{27}$ memperlihatkan bahwa pendidikan berpengaruh terhadap kinerja karyawan. Berdasarkan penelitian-penelitian terdahulu ini pembahasan tentang kinerja karyawan secara konsisten diteliti banyak peneliti dari waktu kewaktu dan masih menjadi kajian yang menarik untuk diteliti.

Kebaruan pada penelitian ini adalah dengan adanya variabel pendidikan yang diukur dengan jenjang pendidikan yang dicapai oleh karyawan. Jenjang pendidikan mulai dari SMA, D3, S1 maupun S2 tidak dapat dianalisis secara langsung karena memiliki skala pengukuran ordinal sehingga variabel ini terlebih dahulu diubah menjadi variabel dummy sehingga analisis yang dipilih adalah analisis regresi dengan variabel dummy. Berdasarkan pemaparan tersebut, penelitian ini dilakukan dengan tujuan mengetahui pengaruh kepemimpinan, lingkungan kerja, dan pendidikan terhadap kinerja karyawan PG Rejo Agung Baru Madiun.

\section{Landasan Teori}

\subsection{Kinerja Karyawan}

Kinerja adalah keberhasilan karyawan menyelesaikan beban dan tugas yang diberikan perusahaan. Kinerja merupakan hasil yang diperoleh selama periode waktu tertentu sesuai fungsi dan kegiatan pada bidang pekerjaan tertentu. ${ }^{28}$ Menurut Timpe, kinerja adalah hasil kerja karyawan yang diselesaikan dalam periode waktu tertentu. ${ }^{29}$ Kinerja merupakan hasil kerja secara kuantitas dan kualitas yang dicapai seorang karyawan sesuai beban dan tugas yang diberikan. ${ }^{30}$ Berdasarkan pengertian ini disimpulkan bahwa kinerja merupakan hasil pekerjaan yang mampu dicapai karyawan pada periode waktu tertentu berdasarkan beban dan tugas yang diberikan.

\footnotetext{
${ }^{24}$ Kadek Candra Dwi Cahyani, I Gst Ayu Purnamawati, dan Nyoman Trisna Herawati, "Pengaruh Etika Profesi Auditor, Profesionalisme, Motivasi, Budaya Kerja, Dan Tingkat Pendidikan Terhadap Kinerja Auditor Junior (Studi Empiris Pada Kantor Akuntan Publik Di Bali)," JIMAT (Jurnal IImiah Mahasiswa Akuntansi S1) 3, no. 1 (2015).

${ }^{25}$ Miranda Diah Ratnasari dan Bambang Swasto Sunuharyo, "Pengaruh Materi Pendidikan dan Pelatihan Terhadap Efektivitas Pelatihan Karyawan Melalui Variabel Mediator Kemampuan Kerja Karyawan (Studi Pada Karyawan Pt Petrokimia Gresik)," Jurnal Administrasi Bisnis 58, no. 1 (2018): 210.

${ }^{26}$ Israwanti Patarai, Mustari, dan Mansur Azis, "Motivasi Mengajar, Kompetensi Profesional dan Tingkat Pendidikan terhadap KInerja Guru," Jurnal Mirai Management 3, no. 2 (2018): 120.

27 Imelda Ogi, Peggy Mekel, dan Winda Rori, “Pendidikan, Pelatihan Dan Penempatan Kerja Pengaruhnya Terhadap Kinerja Pegawai Di Kantor Inspektorat Kota Manado," Jurnal Riset Ekonomi, Manajemen, Bisnis dan Akuntansi 2, no. 2 (2014): 1284, https://doi.org/10.35794/emba.v2i2.4714.

${ }^{28}$ Priansa, Perencanaan dan Pengembangan Sumber Daya Manusia, 270.

${ }^{29}$ Amirullah, Pengantar Manajemen (Jakarta: Mitra Wacana Media, 2015), 231.

${ }^{30}$ Mangkunegara, Manajemen Sumber Daya Manusia Perusahaan, 67.
} 
Penilaian kinerja digunakan untuk menilai kinerja karyawan. Penilaian kinerja adalah proses yang dijalankan suatu perusahaan untuk menilai keberhasilan karyawan menyelesaikan tanggung jawab dan tugas dalam periode waktu tertentu. Rivai dan Sagala mengungkapkan bahwa penilaian kinerja merujuk pada suatu aturan yang disusun secara terstruktur dan formal yang berfungsi menilai dan mengukur sifat-sifat yang berhubungan dengan pekerjaan dan hasil kerja serta memuat penilaian tentang perilaku dan kedisiplinan karyawan. ${ }^{31}$ Penilaian kinerja karyawan dapat diukur dengan membandingkan standar pekerjaan yang ditetapkan perusahaan dengan hasil kerja yang mampu dicapai karyawan. Jika hasil pekerjaan sama dengan atau lebih dari standar pekerjaan yang ditetapkan maka kinerja karyawan masuk kriteria sesuai/baik. ${ }^{32}$ Menurut Kasmir dalam melakukan penilaian kinerja, suatu perusahaan harus menerapkan 3 asas objektif, adil dan transparan. ${ }^{33}$

Menurut Kasmir, kemampuan dan keahlian, pengetahuan, rancangan kerja, kepribadian, kepemimpinan, budaya organisasi, kepuasan kerja, lingkungan kerja, loyalitas, komitmen serta disiplin kerja merupakan faktor-faktor yang memengaruhi kinerja. ${ }^{34}$ Simanjuntak berpendapat bahwa kinerja dipengaruhi oleh kualitas dan kemampuan karyawan (pendidikan/pelatihan), sarana pendukung serta supra sarana. ${ }^{35}$ Menurut Suparyadi, untuk mengukur kinerja karyawan dapat dilakukan dengan mengukur kuantitas/output, kualitas, ketepatan waktu, kreativitas, dan kerjasama yang dilakukan oleh karyawan. ${ }^{36}$

\subsection{Kepemimpinan}

Kepemimpinan merupakan proses yang dilakukan untuk memengaruhi aktifitas karyawan dalam rangka merumuskan dan mencapai tujuan yang diinginkan. ${ }^{37}$ Kepemimpinan diartikan sebagai proses yang dilakukan pemimpin/pimpinan dalam memberikan arahan dan memengaruhi karyawan agar mampu melaksanakan tugas yang telah diberikan. ${ }^{38}$ Kepemimpinan merupakan bagian terpenting dalam perusahaan karena kepemimpinan yang baik dan optimal bisa digunakan untuk mengelola SDM dan SDA perusahaan dan memanfaatkannya secara optimal. ${ }^{39}$ Berdarkan pengertian tersebut, kepemimpinan merupakan suatu proses penting dalam rangka memengaruhi karyawan untuk mampu melaksanakan beban dan tugas sesuai arahan dan tanggung jawab. Kepemimpinan memuat beberapa unsur antara

\footnotetext{
${ }^{31}$ Priansa, Perencanaan dan Pengembangan Sumber Daya Manusia, 271.

32 Bangun, Manajemen Sumber Daya Manusia, 231.

${ }^{33}$ Kasmir, Manajemen Sumber Daya Manusia (Teori dan Praktek), 201.

${ }^{34}$ Kasmir, Manajemen Sumber Daya Manusia (Teori dan Praktik), 189-93.

${ }^{35}$ Widodo, Manajemen Pengembangan Sumber Daya Manusia, 133.

${ }^{36}$ Suparyadi, Manajemen Sumber Daya Manusia, 313-15.

${ }^{37}$ Sudarmayanti, Manajemen Sumber Daya Manusia, 249.

${ }^{38}$ Sule dan Saifullah, Pengantar Manajemen, 255.

${ }^{39}$ Sudarmayanti, Manajemen Sumber Daya Manusia, 249.
} 
lain kumpulan orang, kekuasaan, memngaruhi, dan nilai. ${ }^{40}$ Menurut Fielder, untuk mengukur kepemimpinan dapat dilakukan melalui hubungan pemimpin dengan anggota hal ini digunakan mengukur tingkat keyakinan kepercayaan dan rasa hormat karyawan terhadap pimpinannya, struktur tugas dimaksudkan untuk memperjelas tugas karyawan, semakin jelas tugas yang diberikan maka semakin baik hasil pekerjaan yang akan dijalankan serta kekuasaan jabatan atau tingkat pengaruh yang dimiliki oleh pimpinan. ${ }^{41}$

\subsection{Lingkungan Kerja}

Suatu keadaan yang di sekeliling karyawan dan memengaruhi karyawan menyelesaikan tugas yang diberikan merupakan pengertian dari Lingkungan kerja. ${ }^{42}$ Lingkungan kerja mampu memberikan dampak positif maupun negatif kepada karyawan dalam menyelesaiakan pekerjaannya. Semakin baik kondisi atau lingkungan kerja maka karyawan akan dapat memberikan performansi yang optimal yang pada akhirnya dapat memengaruhi kinerja yang dilakukan. Lingkungan kerja harus didesai dengan baik agar karyawan nyaman dan betah dalam melakukan pekerjaan yang ditugaskan kepadanya. Menurut Nitisemito, suasana/kondisi kerja karyawan, hubungan antar rekan kerja, hubungan karyawan dengan pimpinan, dan ketersediaan fasilitas kerja yang lengkap, memadahi, serta mutakhir merupakan indikator lingkungan kerja. ${ }^{43}$

\subsection{Pendidikan}

Suatu proses dalam jangka yang panjang sesuai dengan prosedur yang teratur dan terorganisir merupakan pengertian tingkat pendidikan. ${ }^{44}$ Menurut Hasibuan, pendidikan erat hubungannya dengan penguatan pengetahuan secara umum dan pengetahuan atas lingkungan secara komprehensif. Pengembangan SDM di Indonesia meliputi pengembangan IQ, EQ, dan SQ. ${ }^{45}$ Dimensi dari tingkat pendidikan yaitu pendidikan formal dengan indikator pendidikan yang diperoleh dibangku sekolah. ${ }^{46}$

\footnotetext{
${ }^{40}$ Bangun, Manajemen Sumber Daya Manusia, 240-41.

${ }^{41}$ Bangun, 348.

${ }^{42}$ Nitisemito, Manajemen Personalia: Manajemen Sumber Daya Manusia, 183.

${ }^{43}$ Rahman, Ilmu Administrasi, 48.

${ }^{44}$ Patarai, Mustari, dan Azis, "Motivasi Mengajar, Kompetensi Profesional dan Tingkat Pendidikan terhadap KInerja Guru," 123.

${ }^{45}$ Yohanes Nababan, Hendra Tawas, dan Jantje Uhing, "Pengaruh Pendidikan Dan Pelatihan Kerja Terhadap Kinerja Karyawan Pt.PIn (Persero) Area Manado," Jurnal Riset Ekonomi, Manajemen, Bisnis dan Akuntansi 4, no. 3 (2016): 753, https://doi.org/10.35794/emba.v4i3.14417.

${ }^{46}$ Wirawan, Bagia, dan Susila, "Pengaruh Tingkat Pendidikan Dan Pengalaman Kerja Terhadap Kinerja," 62.
} 


\section{Metode Penelitian}

Desain penelitian asosiatif dipilih untuk menjawab tujuan pada penelitian ini. Semua karyawan tetap PG Rejo Agung Baru Madiun yang terdiri dari 45 karyawan staf dan 200 karyawan non staf (total 245 karyawan) merupakan populasi dalam penelitian ini. Populasi penelitian memiliki anggota yang tidak homogen, sehingga penentuan sampel dilakukan dengan proportionate stratified random sampling. Tingkat kesalahan $(\mathrm{e})=10 \%$ yang merupakan besarnya maksimum kesalahan dalam pengambilan sampel. Hasil perhitungan sampel dengan rumus Slovin ditunjukkan pada persamaan berikut sebagai berikut: ${ }^{47}$

$$
\begin{aligned}
n & =\frac{N}{1+\left(N e^{2}\right)} \\
& =\frac{245}{1+\left(245 \times 0,1^{2}\right)} \\
& =\frac{245}{1+2,45}=71,01=72
\end{aligned}
$$

Hasil perhitungan memperlihatkan jumlah sampel 72 karyawan. Perbandingan karyawan staf dan karyawan non staff adalah 45:200 atau 9:40 sehingga diambil sampel sebanyak 13 karyawan staff dan 58 karyawan non staff.

Angket/kuesioer dipilih sebagai alat untuk mengumpulkan data. Angket/kuesioner berisi daftar pernyataan yang selanjutnya diberikan kepada responden. Responden diminta untuk diberikan pendapat/jawaban yang paling sesuai dengan kondisi responden. Angket/kuesioner bersifat tertutup. Artinya responden menjawab sesuai dengan pilihan yang telah disediakan dan tidak diperbolehkan menentukan jawaban diluar pilihan yang ada. Sebelum menyusun angket/kuesioner, terlebih dahulu disusun kisi-kisi untuk mempermudah pembuatan instrumen penelitian seperti ditunjukkan pada Tabel 2.

Tabel 2. Kisi-Kisi Instrumen Penelitian

\begin{tabular}{llc}
\hline \multicolumn{1}{c}{ Variabel } & \multicolumn{1}{c}{ Indikator } & Item \\
\hline Kinerja \\
Karyawan $(\mathrm{Y})$ & 1. Kuantitas & $1-2$ \\
\cline { 2 - 3 } & 2. Kualitas & $3-4$ \\
\cline { 2 - 3 } & 3. Ketepatan waktu & $5-6$ \\
\cline { 2 - 3 } & 4. Kreativitas & 7-8 \\
\cline { 2 - 3 } & 5. Kerja sama & 9-10 \\
\hline Kepemimpinan & 1. Hubungan pemimpin anggota & $11-12$ \\
\cline { 2 - 3 } & 2. Struktur tugas & $13-14$ \\
\hline
\end{tabular}

\footnotetext{
${ }^{47}$ V Wiratna Sujarweni, Metodologi Penelitian Bisnis dan Ekonomi (Yogyakarta: Pustaka Baru Press, 2015), 56.
} 
Jurnal Ekonomi Syariah dan Hukum Ekonomi Syariah

\begin{tabular}{|c|c|c|}
\hline Variabel & Indikator & Item \\
\hline & 3. Kekuasaan jabatan & $15-16$ \\
\hline \multirow{4}{*}{$\begin{array}{l}\text { Lingkungan } \\
\text { Kerja (X2) }\end{array}$} & 1. Suasana kerja & $17-18$ \\
\hline & 2. Hubungan dengan rekan kerja & $19-20$ \\
\hline & $\begin{array}{l}\text { 3. Hubungan karyawan dan } \\
\text { pimpinan }\end{array}$ & $21-22$ \\
\hline & 4. Ketersedian fasilitas kerja & $23-24$ \\
\hline Pendidikan (X3) & $\begin{array}{l}\text { Pendidikan formal yang terakhir } \\
\text { ditamatkan 1.SMA 2.D3 3. S1/S2 }\end{array}$ & 25 \\
\hline
\end{tabular}

Nilai dari masing-masing variabel diukur menggunakan skala Likert. Skala ini digunakan untuk mengukur persepsi, pendapat, serta kondisi yang dirasakan karyawan. ${ }^{48}$ Skala likert yang digunakan adalah sangat setuju (SS), sejutu (S), kurang setuju (KS), tidak setuju (TS), dan sangat tidak setuju (STS).

Pengujian validitas dan reliabilitas, pengujian asumsi klasik, dan analisis regresi dengan variabel dummy dipilih untuk analisis data pada penelitian ini. Variabel bebas adalah kepemimpinan, lingkungan kerja dan pendidikan sedangkan variabel terikat adalah kinerja karyawan. Pada penelitian ini digunakan variabel dummy untuk menjelaskan variabel $X_{3}$. Dasar/base yang digunakan adalah pendidikan S1/S2 sehingga dummy yang digunakan adalah dummy untuk pendidikan SMA dan pendidikan D3. Hasil analisisnya nanti dibandingkan antara dummy SMA dengan base serta dummy D3 dengan basenya. Model regresi dengan variabel dummy pada penelitian ini adalah sebagi berikut

$$
Y=a+b_{1} X_{1}+b_{2} X_{2}+b_{3} D_{1}+b_{4} D_{2}+\varepsilon
$$

Keterangan:

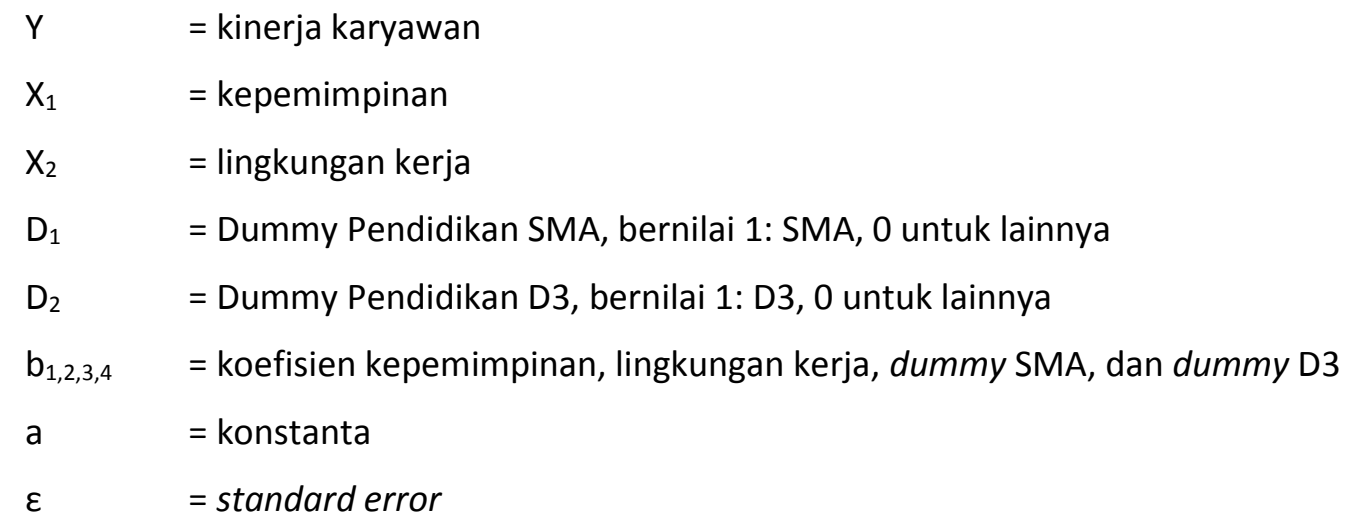

\footnotetext{
${ }^{48}$ Sugiono, Metode Penelitian Kuantitatif, Kualitatif, dan R\&D (Bandung: Alfa Beta, 2017).
} 
Hipotesis penelitian berdasarkan tujuan dan persamaan model regresi sebagai berikut

$H_{a 1}$ : Kepemimpinan memiliki pengaruh positif terhadap kinerja karyawan secara parsial

$\mathrm{H}_{\mathrm{a} 2}$ : Lingkungan kerja memiliki pengaruh positif terhadap kinerja karyawan secara parsial

$\mathrm{H}_{\mathrm{a} 3}$ : Kinerja karyawan berpendidikan SMA lebih rendah dibandingkan kinerja karyawan berpendidikan S1/S2

$\mathrm{H}_{\mathrm{a} 4}$ : Kinerja karyawan berpendidikan D3 lebih rendah dibandingkan kinerja karyawan berpendidikan $\mathrm{S} 1 / \mathrm{S} 2$

$\mathrm{H}_{\mathrm{a} 5}$ : Kepemimpinan, Lingkungan kerja dan pendidikan berpengaruh terhadap kinerja karyawan secara simultan

\section{Hasil dan Pembahasan}

Instrumen yang disusun selanjutnya diujicobakan terlebih dahulu kepada 30 responden untuk mendapatkan hasil validitas dan reliabilitas instrument yang dimiliki. Instrumen yang valid dan reliabel inilah yang selanjutnya digunakan dalam pengambilan data penelitian. Suatu instrumen valid jika nilai $\boldsymbol{r}_{\text {hitung }}>0,361$ dan reliabel jika nilai cronbach's alpha lebih dari 0,6. Hasil analisis menunjukkan bahwa 10 item pernyataan variabel kinerja, 6 item pernyataan variabel kepemimpinan, dan 8 item pernyataan variabel lingkungan kerja valid karena nilai rhitung $>0,361$. Selain itu, nilai $C A>0,6$ untuk semua variabel sehingga semua variabel pada penelitian ini reliabel. Hasil ini menunjukkan bahwa data ujicoba instrumen telah memenuhi asumsi validitas dan reliabilitas sehingga instrumen ini dapat digunakan sebagai instrumen pengumpulan data penelitian.

Model regresi dengan variabel dummy dapat digunakan ketika memenuhi pengujian asumsi klasik (normalitas residual, heteroskedastisitas/kesamaan varian, autokorelasi, dan multikolinieritas). Hasil pengujian asumsi klasik ditunjukkan pada Tabel 3 hingga Tabel 6.

Tabel 3. Hasil Pengujian Normalitas

\begin{tabular}{ccc}
\hline KS & $\mathbf{N}$ & Sig \\
\hline 0,068 & 72 & 0,200
\end{tabular}

Sumber: Data diolah 2020

Tabel 3 menunjukkan hasil pengujian normalitas residual. Hasil perhitungan menunjukkan bahwa nilai sig $=0,068>0,05$ yang artinya residual mengikuti distribusi normal. 
Tabel 4. Hasil Pengujian Heteroskedastisitas

\begin{tabular}{lll}
\hline Variabel & $\mathbf{t}_{\text {hitung }}$ & Sig \\
\hline$X_{1}$ & $-0,052$ & 0,959 \\
\hline$X_{2}$ & 0,123 & 0,902 \\
\hline$D_{1}$ & $-0,716$ & 0,476 \\
\hline$D_{2}$ & $-1,256$ & 0,214 \\
\hline
\end{tabular}

Sumber: Data diolah 2020

Hasil perhitungan pada Tabel 4 memperlihatkan bahwa tidak terdapat pengaruh variabel independen terhadap harga mutlak residual karena semua nilai sig>0,05. Berdasarkan hasil ini, disimpukan bahwa varian residual homogen sehingga pengujian non heteroskedastisitas terpenuhi.

Tabel 5. Hasil Pengujian Autokorelasi

\begin{tabular}{ccc}
\hline DW & du & 4-du \\
\hline 2,031 & 1,705 & 2,295
\end{tabular}

Sumber: Data diolah 2020

Tabel 5 menunjukkan hasil pengujian autokorelasi metode durbin watson. Hasil perhitungan menunjukkan bahwa nilai $d w=2,031$. Karena $d u=1,705<2,031<4-d u=2,295$ maka pada penelitian ini tidak terjadi autokorelasi sehingga pengujian non autokorelasi terpenuhi.

\section{Tabel 6. Hasil Pengujian Multikolinieritas}

\begin{tabular}{ccc}
\hline Variabel & TOL & VIF \\
\hline $\mathrm{X}_{1}$ & 0,386 & 2,594 \\
\hline $\mathrm{X}_{2}$ & 0,381 & 2,622 \\
\hline $\mathrm{D}_{1}$ & 0,637 & 1,571 \\
\hline $\mathrm{D}_{2}$ & 0,633 & 1,580 \\
\hline \multicolumn{2}{l}{ Sumber: Data diolah 2020}
\end{tabular}

Hasil pengujian pada Tabel 6 memperlihatkan bahwa nilai nilai VIF semua variabel lebih dari 0,1 sehingga tidak terjadi multikolinieritas pada penelitian ini. Berdasarkan pengujian asumsi klasik diketahui bahwa semua asumsi telah terpenuhi sehingga uji $\mathrm{t}$ dan uji $\mathrm{F}$ dapat digunakan. Hasil uji t ditunjukkan pada Tabel 7 sedangkan hasil uji $\mathrm{F}$ ditunjukkan pada Tabel 8. 
Tabel 7. Koefisien Model Regresi

\begin{tabular}{lllll}
\hline Variabel & Beta & $\mathbf{t}$ & Sig. & Ket \\
\hline Konstanta & 7,178 & 2,228 & 0,029 & Signifikan \\
\hline $\mathrm{X}_{1}$ & 0,786 & 4,650 & 0,000 & Signifikan \\
\hline $\mathrm{X}_{2}$ & 0,426 & 3,027 & 0,004 & Signifikan \\
\hline $\mathrm{D}_{1}$ & 1,652 & 2,097 & 0,040 & Signifikan \\
\hline $\mathrm{D}_{2}$ & 1,170 & 1,033 & 0,305 & Tidak signifikan \\
\hline
\end{tabular}

Sumber: Data diolah 2020

Berdasarkan Tabel 7 hasil temuan penelitian sebagai berikut

a. Kepemimpinan $\left(X_{1}\right)$ memiliki nilai $t_{\text {hitung }}=4,650>1,668$ artinya tolak $H_{01}$ artinya kepemimpinan memiliki pengaruh positif terhadap kinerja karyawan secara parsial. Koefisien regresi $b_{1}=0,786$ mengindikasikan peningkatan kepemimpinan akan diikuti dengan peningkatan kinerja karyawan. Lebih jauh, jika kepemimpinan ditingkatkan 1 satuan maka kinerja karyawan juga meningkat sebesar 0,786 satuan.

b. Lingkungan kerja $\left(\mathrm{X}_{2}\right)$ memiliki nilai thitung $=3,027>1,668$ artinya tolak $\mathrm{H}_{02}$ dan disimpulkan bahwa lingkungan kerja memiliki pengaruh positif terhadap kinerja karyawan secara parsial. Nilai koefisien regresi $b_{2}=0,426$ mengindikasikan peningkatan lingkungan kerja akan diikuti dengan peningkatan kinerja karyawan. Lebih jauh, jika lingkungan kerja ditingkatkan 1 satuan maka kinerja karyawan akan mengalami peningkatan sebesar 0,426 satuan.

c. Pendidikan SMA $\left(D_{1}\right)$ memiliki nilai $t_{\text {hitung }}=2,097>-1,668$ artinya tolak $H_{03}$ dan disimpulkan bahwa kinerja karyawan berpendidikan SMA lebih tinggi dibandingkan kinerja karyawan berpendidikan S1/S2. Artinya pendidikan SMA memiliki pengaruh yang negatif terhadap kinerja karyawan $(\mathrm{Y})$. Nilai koefisien regresi $b_{3}=1,652$ mengindikasikan bahwa karyawan pendidikan SMA kinerjanya lebih tinggi 1,652 dibandingkan kinerja karyawan dengan pendidikan S1/S2. Artinya semakin tinggi pendidikan, kinerja karyawan semakin rendah.

d. Pendidikan D3 $\left(D_{2}\right)$ memiliki nilai thitung $=1,033>-1,668$ artinya tolak $\mathrm{H}_{04}$ dan disimpulkan bahwa kinerja karyawan berpendidikan $\mathrm{D}_{3}$ lebih tinggi dibandingkan kinerja karyawan berpendidikan S1/S2. Artinya pendidikan $D_{3}$ memiliki pengaruh negative yang terhadap kinerja karyawan (Y). Nilai koefisien regresi $b_{4}=1,170$ mengindikasikan bahwa karyawan pendidikan $D_{3}$ kinerjanya lebih tinggi 1,170 dibandingkan kinerja karyawan dengan pendidikan S1/S2. Artinya semakin tinggi pendidikan, kinerja karyawan semakin rendah. 
Jurnal Ekonomi Syariah dan Hukum Ekonomi Syariah

Tabel 8. ANOVA

\begin{tabular}{cccccc}
\hline Model & SS & df & MS & $F$ & Sig. \\
\hline Regresi & 713,857 & 4 & 178,464 & 34,780 & 0,000 \\
\hline Residual & 343,796 & 67 & 5,131 & & \\
\hline Total & 1057,653 & 71 & & &
\end{tabular}

Sumber: Data diolah 2020

Nilai $F_{\text {hitung }}=34,780$ dengan nilai sig $=0,000$ pada Tabel 8 menunjukkan bahwa nilai $F_{\text {hitung }}=34,780>2,509$ maka tolak $\mathrm{H}_{05}$ yang artinya kepemimpinan, lingkungan kerja, dan pendidikan berpengaruh terhadap kinerja karyawan PG Rejo Agung Baru Madiun secara simultan.

Tabel 9. Koefisien Determinasi

\begin{tabular}{cc}
\hline $\mathbf{R}$ & $\mathbf{R}^{\mathbf{2}}$ \\
\hline 0,822 & 0,675 \\
\hline
\end{tabular}

Sumber: Data diolah 2020

Tabel 9 menunjukkan bahwa $\mathrm{R}=0,822$ dan $\mathrm{R}^{2}=0,675$. Nilai $\mathrm{R}=0,822$ menunjukkan bahwa hubungan antara kepemimpinan, lingkungan kerja, dan pendidikan terhadap kinerja karyawan adalah hubungan yang sangat kuat. Sedangkan nilai $R^{2}=0,675$ menunjukkan kontribusi yang diberikan ketiga variabel (kepemimpinan, lingkungan kerja, dan pendidikan) terhadap kinerja karyawan adalah $67,5 \%$ sisanya senilai $32,5 \%$ merupakan kontribusi yang dijelaskan variabel yang tidak diteliti.

\subsection{Pengaruh Kepemimpinan terhadap Kinerja Karyawan}

Hasil uji t memperlihatkan bahwa variabel kepemimpinan $\left(X_{1}\right)$ memiliki pengaruh positif terhadap variabel kinerja karyawan $(Y)$ secara parsial. Hal ini didasarkan pada nilai $t_{\text {hitung }}=4,650>1,668$ artinya tolak $\mathrm{H}_{01}$. Jadi dapat disimpulkan bahwa secara parsial kepemimpinan memberikan pengaruh yang positif terhadap kinerja karyawan. Hasil pengujian ini mendukung teori Kasmir ${ }^{49}$ serta sesuai dengan penelitian Penelitian Wa Ode Zusnita muizu dkk ${ }^{50}$, Dwi Yuniarti dan Erlian Suprianto ${ }^{51}$, Made Suprapta dkk $^{52}$ serta Sri Rustilah ${ }^{53}$ yang menjelaskan bahwa kepemimpinan berpengaruh positif terhadap kinerja.

\footnotetext{
${ }^{49}$ Kasmir, Manajemen Sumber Daya Manusia (Teori dan Praktik), 189.

${ }^{50}$ Muizu, Kaltum, dan Sule, “Pengaruh Kepemimpinan Terhadap Kinerja Karyawan,” 75.

${ }^{51}$ Yuniarti dan Suprianto, "Pengaruh Gaya Kepemimpinan Dan Tingkat Pendidikan Terhadap Kinerja Karyawan Pada Direktoreat Operasi/Produksi Pt. X," 11.

52 Suprapta, Sintaasih, dan Riana, "Pengaruh kepemimpinan terhadap kepuasan kerja dan kinerja karyawan (studi pada Wake Bali Art Market Kuta-Bali)," 437.

53 Rustilah, "Pengaruh Gaya Kepemimpinan Dan Kompensasi Terhadap Kepuasan Kerja Dan Kinerja Pegawai Tenaga Kontrak," 219.
} 
Hasil koefisien regresi menunjukkan nilai 0,786 yang artinya kepemimpinan berpengaruh positif terhadap kinerja karyawan. Ketika kepemimpinan semakin baik, pemimpin mampu mengelola dan membimbing karyawan dalam mengerjakan tugas dan tanggung jawab yang diberikan kepada karyawan maka karyawan akan semakin bersemangat yang pada akhirnya kinerjanya semakin meningkat. Karyawan yang memiliki kinerja yang baik akan mendatangkan keuntungan pada perusahaan yang pada akhirnya mengakibatkan perusahaan memiliki kemampuan untuk bertahan dalam persaingan dalam dunia bisnis yang semakin ketat di kemudian hari.

\subsection{Pengaruh Lingkungan Kerja terhadap Kinerja Karyawan}

Hasil uji t menunjukkan bahwa variabel lingkungan kerja $\left(X_{2}\right)$ memiliki pengaruh positif terhadap variabel kinerja karyawan $(\mathrm{Y})$ secara parsial. Hal ini didasarkan pada nilai $t_{\text {hitung }}=3,027>1,668$ sehingga $\mathrm{H}_{02}$ ditolak. Jadi dapat disimpulkan bahwa secara parsial lingkungan memiliki pengaruh positif terhadap kinerja karyawan. Hasil uji t ini sesuai dengan teori Kasmir serta penelitian Apfia Ferawati ${ }^{54}$, Daniel Surjosuseno ${ }^{55}$ Tomy Sun Siagian dan Hazmanan Khair ${ }^{56}$, Fernando Reinhard Tjiabrata dkk ${ }^{57}$, Rizal Nabawi ${ }^{58}$, serta Elizar dan Hasrudy Tanjung ${ }^{59}$ yang membuktikan bahwa lingkungan kerja memiliki pengaruh positif terhadap kinerja karyawan.

Nilai koefisien regresi sebesar 0,426 menunjukkan bahwa lingkungan kerja mampu memberikan pengaruh yang positif pada kinerja karyawan. Implikasinya, ketika lingkungan kerja dikondisikan dengan baik (mampu memberikan rasa nyaman) akan membuat karyawan bekerja dengan baik. Kondisi lingkungan kerja yang nyaman membuat karyawan betah berada di perusahaan. Pada akhirnya kerja karyawan semakin baik dan perusahaan memperoleh hasil yang baik dari kinerja karyawan yang semakin baik.

\subsection{Pengaruh Pendidikan terhadap Kinerja Karyawan}

Hasil pengujian uji t menunjukkan bahwa variabel pendidikan $\left(X_{3}\right)$ berpengaruh negatif dan signifikan terhadap variabel kinerja karyawan $(Y)$ secara parsial. Hal ini didasarkan pada hasil uji t pada $D_{1}$ dan $D_{2}$ yang menunjukkan bahwa terdapat perbedaan kinerja karyawan yang memiliki pendidikan SMA dan $D_{3}$ dengan karyawan yang berpendidikan

\footnotetext{
${ }^{54}$ Ferawati, “Pengaruh Lingkungan Kerja Dan Disiplin Kerja Terhadap Kinerja Karyawan Pt. Cahaya Indo Persada."

${ }^{55}$ Surjosuseno, "Pengaruh Lingkungan Kerja Dan Motivasi Kerja Terhadap Kinerja Karyawan Pada Bagian Produksi UD Pabrik Ada Plastic," 177.

${ }^{56}$ Siagian dan Khair, "Pengaruh Gaya Kepemimpinan Dan Lingkungan Kerja Terhadap Kinerja Karyawan Dengan Kepuasan Kerja Sebagai Variabel Intervening," 65.

${ }^{57}$ Tjibrata, Lumanaw, dan Dotulang O.H, “Pengaruh Beban Kerja Dan Lingkungan Kerja Terhadap Kinerja Karyawan Pt.Sabar Ganda Manado," 1578.

${ }^{58}$ Nabawi, "Pengaruh Lingkungan Kerja, Kepuasan Kerja dan Beban Kerja Terhadap Kinerja Pegawai," 170.

${ }^{59}$ Elizar dan Tanjung, “Pengaruh Pelatihan, Kompetensi, Lingkungan Kerja terhadap Kinerja Pegawai," 46.
} 
S1/S2. Hal ini seperti teori yang disampaikan oleh Suparno Eko Widodo serta penelitian Kadek Candra Dwi Cahyani dkk ${ }^{60}$, Miranda Diah Ratnasari dan Bambang Swasti Sunuharyo ${ }^{61}$, Iswaranti Patarai $\mathrm{dkk}^{62}$ serta Wenda Jennifer Rori $\mathrm{dkk}^{63}$ yang menyatakan bahwa pendidikan berpengaruh terhadap kinerja karyawan. ${ }^{64}$

Hasil koefisien regresi sebesar 1,652 dan 1,170 menunjukkan bahwa karyawan dengan pendidikan SMA mampu $D_{3}$ memberikan kinerja yang lebih baik dibandingkan karyawan berpendidikan D3/S1/S2. Seharusnya semakin tinggi pendidikan yang dimiliki maka kinerja yang dihasilkan harus lebih tinggi. Hal ini mungkin terjadi ketika jenis pekerjaan yang dilakukan antara karyawan ini berbeda. Sehingga menghasilkan kinerja karyawan yang berbeda pula.

\subsection{Pengaruh Kepemimipinan, Lingkungan kerja, dan Pendidikan terhadap Kinerja Karyawan}

Hasil pengujian uji F menunjukkan bahwa variabel kepemimpinan $\left(X_{1}\right)$, lingkungan kerja $\left(X_{2}\right)$ dan pendidikan $\left(X_{3}\right)$ berpengaruh secara simultan terhadap variabel kinerja karyawan (Y). Hal ini didasarkan pada nilai $F_{\text {hitung }}=34,780>2,509$ maka tolak $\mathrm{H}_{05}$ yang artinya kepemimpinan, lingkungan kerja, dan pendidikan berpengaruh terhadap kinerja karyawan PG Rejo Agung Baru Madiun secara simultan. Hasil ini memberikan gambaran bahwa untuk meningatkan kinerja karyawan, pihak perusahaan dapat meningkatkan dari sisi kepemimpinan, lingkungan kerja serta pendidikan. Untuk meningkatkan kinerja, pihak perusahaan dapat meningkatkan kepemimpinan terlebih dahulu. Baru kemudian dapat meningkatkan

\section{Penutup}

Perusahaan harus mulai memperhatikan beberapa hal sebagai upaya meningkatkan kinerja kayawannya. Untuk meningkatkan kinerja karyawan, suatu perusahaan dapat memulainya dengan menerapkan kepemimpinan yang baik dan terorganisir serta memiliki pandangan yang luas sehingga mampu menangkap kondisi yang ada dilapangan untuk dimanfaatkan dan dikembangkan sebagai suatu keunggulan perusahaan. Setelah kepemimpinan baik, dapat mulai memperhatikan lingkungan kerja karyawan apakah sudah sesuai dengan yang diinginkan karyawan dan perlu

\footnotetext{
${ }^{60}$ Cahyani, Purnamawati, dan Herawati, "Pengaruh Etika Profesi Auditor, Profesionalisme, Motivasi, Budaya Kerja, Dan Tingkat Pendidikan Terhadap Kinerja Auditor Junior (Studi Empiris Pada Kantor Akuntan Publik Di Bali)."

${ }^{61}$ Ratnasari dan Sunuharyo, "Pengaruh Materi Pendidikan dan Pelatihan Terhadap Efektivitas Pelatihan Karyawan Melalui Variabel Mediator Kemampuan Kerja Karyawan (Studi Pada Karyawan Pt Petrokimia Gresik)," 210.

62 Patarai, Mustari, dan Azis, "Motivasi Mengajar, Kompetensi Profesional dan Tingkat Pendidikan terhadap KInerja Guru," 120.

${ }^{63}$ Ogi, Mekel, dan Rori, "Pendidikan, Pelatihan Dan Penempatan Kerja Pengaruhnya Terhadap Kinerja Pegawai Di Kantor Inspektorat Kota Manado," 1284.

${ }^{64}$ Widodo, Manajemen Pengembangan Sumber Daya Manusia, 133.
} 
adanya peningkatan. Selain kepemimpinan dan lingkungan kerja, yang tidak kalah penting adalah pendidikan. Pendidikan juga memberikan sumbangan kepada kinerja karyawan. Pendidikan yang tinggi harusnya mampu memberikan performansi kinerja yang lebih tinggi dibandingkan dengan pendidikan yang dibawahnya. Sehingga untuk meningkatkan kinerja karyawan, perusahaan dapat mulai memberikan batasan pendidikan berdasarkan tingkat kesulitan yang akan dihadapi.

Pada penelitian selanjutnya dapat dilakukan penelitian serupa dengan menambahkan variabel lama bekerja dan posisi pekerjaan untuk menunjang hasil yang diperoleh dari penelitian ini. Hal ini dikarenakan hasil penelitian masih menunjukkan bahwa pendidikan yang lebih rendah justru memberikan hasil kinerja yang lebih tinggi tanpa memperhatikan posisi pekerjaan, tingkat kesulitan pekerjaan serta lama bekerja karyawan tersebut. Bisa jadi yang memiliki pendidikan D3/S1/S2 memiliki kinerja yang kurang karena masih baru bergabung sedangkan karyawan dengan pendidikan SMA memiliki kinerja yang lebih tinggi karena lebih berpengalaman dan sudah terbiasa dengan pekerjaan yang dilakukan.

\section{DAFTAR PUSTAKA}

Amirullah. Pengantar Manajemen. Jakarta: Mitra Wacana Media, 2015.

Bangun, Wilson. Manajemen Sumber Daya Manusia. Jakarta: Erlangga, 2012.

Cahyani, Kadek Candra Dwi, I Gst Ayu Purnamawati, dan Nyoman Trisna Herawati. "Pengaruh Etika Profesi Auditor, Profesionalisme, Motivasi, Budaya Kerja, Dan Tingkat Pendidikan Terhadap Kinerja Auditor Junior (Studi Empiris Pada Kantor Akuntan Publik Di Bali)." JIMAT (Jurnal IImiah Mahasiswa Akuntansi S1) 3, no. 1 (2015).

Dewi, Desak Ketut Ratna, I Wayan Suwendra, dan Ni Nyoman Yulianthini. "Pengaruh Tingkat Pendidikan dan Motivasi Kerja terhadap Kinerja Karyawan." Jurnal Manajemen Indonesia 4, no. 1 (2016).

Elizar, Elizar, dan Hasrudy Tanjung. "Pengaruh Pelatihan, Kompetensi, Lingkungan Kerja terhadap Kinerja Pegawai." Maneggio: Jurnal IImiah Magister Manajemen 1, no. 1 (2018): 46-58. https://doi.org/10.30596/maneggio.v1i1.2239.

Ferawati, Apfia. "Pengaruh Lingkungan Kerja Dan Disiplin Kerja Terhadap Kinerja Karyawan Pt. Cahaya Indo Persada." Jurnal Agora 5, no. 1 (2017): 1-131.

Hasibuan, Siti Maisarah, dan Syaiful Bahri. "Pengaruh Kepemimpinan, Lingkungan Kerja dan Motivasi Kerja Terhadap Kinerja." Maneggio: Jurnal IImiah Magister $\begin{array}{lllll}\text { Manajemen } & 1 \text { no. } & 1 & \text { (2018): }\end{array}$ https://doi.org/10.30596/maneggio.v1i1.2243.

Kasmir. Manajemen Sumber Daya Manusia (Teori dan Praktik). Jakarta: Rajawali Pers, 2016.

Mangkunegara, Anwar Prabu. Manajemen Sumber Daya Manusia Perusahaan. Bandung: Remaja, 2013. 
Muizu, Wa Ode Zusnita, Umi Kaltum, dan Ernie T Sule. "Pengaruh Kepemimpinan Terhadap Kinerja Karyawan." PERWIRA-Jurnal Pendidikan Kewirausahaan Indonesia 2, no. 1 (2019): 70-78.

Nababan, Yohanes, Hendra Tawas, dan Jantje Uhing. "Pengaruh Pendidikan Dan Pelatihan Kerja Terhadap Kinerja Karyawan Pt.Pln (Persero) Area Manado." Jurnal Riset Ekonomi, Manajemen, Bisnis dan Akuntansi 4, no. 3 (2016): 751-59. https://doi.org/10.35794/emba.v4i3.14417.

Nabawi, Rizal. “Pengaruh Lingkungan Kerja, Kepuasan Kerja dan Beban Kerja Terhadap Kinerja Pegawai." Maneggio: Jurnal Ilmiah Magister Manajemen 2, no. 2 (2019): 170-83. https://doi.org/10.30596/maneggio.v2i2.3667.

Nitisemito, Alex S. Manajemen Personalia: Manajemen Sumber Daya Manusia. Jakarta: Ghalia Indonesia, 1983.

Ogi, Imelda, Peggy Mekel, dan Winda Rori. “Pendidikan, Pelatihan Dan Penempatan Kerja Pengaruhnya Terhadap Kinerja Pegawai Di Kantor Inspektorat Kota Manado." Jurnal Riset Ekonomi, Manajemen, Bisnis dan Akuntansi 2, no. 2 (2014): 1284-95. https://doi.org/10.35794/emba.v2i2.4714.

Patarai, Israwanti, Mustari, dan Mansur Azis. "Motivasi Mengajar, Kompetensi Profesional dan Tingkat Pendidikan terhadap KInerja Guru." Jurnal Mirai Management 3, no. 2 (2018): 120-33.

Priansa, Donni Juni. Perencanaan dan Pengembangan Sumber Daya Manusia. Bandung: Alfabeta, 2016.

Rahman, Mariati. Ilmu Administrasi. Makasar: Sah Media, 2017.

Ratnasari, Miranda Diah, dan Bambang Swasto Sunuharyo. "Pengaruh Materi Pendidikan dan Pelatihan Terhadap Efektivitas Pelatihan Karyawan Melalui Variabel Mediator Kemampuan Kerja Karyawan (Studi Pada Karyawan Pt Petrokimia Gresik)." Jurnal Administrasi Bisnis 58, no. 1 (2018): 210-18.

Rustilah, Sri. "Pengaruh Gaya Kepemimpinan Dan Kompensasi Terhadap Kepuasan Kerja Dan Kinerja Pegawai Tenaga Kontrak." Journal of Management Review 2, no. 2 (2018): 219. https://doi.org/10.25157/jmr.v2i2.1798.

Siagian, Tomy Sun, dan Hazmanan Khair. "Pengaruh Gaya Kepemimpinan Dan Lingkungan Kerja Terhadap Kinerja Karyawan Dengan Kepuasan Kerja Sebagai Variabel Intervening." Maneggio: Jurnal Ilmiah Magister Manajemen 1, no. 1 (2018): 59-70. https://doi.org/10.30596/maneggio.v1i1.2241.

Sudarmayanti. Manajemen Sumber Daya Manusia. Bandung: CV. Mandar Maju, 2011.

Sugiono. Metode Penelitian Kuantitatif, Kualitatif, dan R\&D. Bandung: Alfa Beta, 2017.

Sujarweni, V Wiratna. Metodologi Penelitian Bisnis dan Ekonomi. Yogyakarta: Pustaka Baru Press, 2015.

Sule, Ernie Tisnawati, dan Kurniawan Saifullah. Pengantar Manajemen. Jakarta: Prenadamedia Group, 2015. 
Suparyadi. Manajemen Sumber Daya Manusia. Yogyakarta: Andi Offset, 2015.

Suprapta, Made, Desak Ketut Sintaasih, dan I Gede Riana. "Pengaruh kepemimpinan terhadap kepuasan kerja dan kinerja karyawan (studi pada Wake Bali Art Market Kuta-Bali)." E-Jurnal Ekonomi dan Bisnis Universitas Udayana, 2015.

Surjosuseno, Daniel. "Pengaruh Lingkungan Kerja Dan Motivasi Kerja Terhadap Kinerja Karyawan Pada Bagian Produksi UD Pabrik Ada Plastic." Agora 3, no. 2 (20 November 2015): 175-79.

Tjibrata, Fernando Reinhard, Bode Lumanaw, dan Lucky Dotulang O.H. "Pengaruh Beban Kerja Dan Lingkungan Kerja Terhadap Kinerja Karyawan Pt.Sabar Ganda Manado." Jurnal EMBA 5 No.2, no. Juni (2017): 1570-80.

Widodo, Suparno Eko. Manajemen Pengembangan Sumber Daya Manusia. Yogyakarta: Pustaka Pelajar, 2015.

Wirawan, Ketut Edy, I Wayan Bagia, dan Gede Putu Agus Jana Susila. "Pengaruh Tingkat Pendidikan Dan Pengalaman Kerja Terhadap Kinerja." Bisma Jurnal Manajamen 5, no. 1 (2019): 60-67.

Yuniarti, Dwi, dan Erlian Suprianto. "Pengaruh Gaya Kepemimpinan Dan Tingkat Pendidikan Terhadap Kinerja Karyawan Pada Direktoreat Operasi/Produksi Pt. X." Jurnal Industri Elektro dan Penerbangan 4, no. 1 (2020): 11-19. 